Article

\title{
Enhancing ethylene selectivity in MTO reaction by incorporating metal species in the cavity of SAPO-34 catalysts
}

\author{
Jiawei Zhong a,b,d, Jingfeng Han ${ }^{\mathrm{b}}$, Yingxu Wei b,\$, Shutao Xu ${ }^{\mathrm{b}}$, Tantan Sun ${ }^{\mathrm{b}}$, Xinwen Guo a, \\ Chunshan Song a,c,\#, Zhongmin Liu b,* \\ a State Key Laboratory of Fine Chemicals, PSU-DUT Joint Center for Energy Research, School of Chemical Engineering, Dalian University of Technology, \\ Dalian 116024, Liaoning, China \\ b National Engineering Laboratory for Methanol to Olefins, State Energy Low Carbon Catalysis and Engineering R\&D Center, Dalian National Laboratory \\ for Clean Energy, iChEM (Collaborative Innovation Center of Chemistry for Energy Materials), Dalian Institute of Chemical Physics, Chinese Academy of \\ Sciences, Dalian 116023, Liaoning, China \\ c EMS Energy Institute, Departments of Energy and Mineral Engineering, and of Chemical Engineering, Pennsylvania State University, University Park, PA \\ 16802, USA \\ d University of Chinese Academy of Sciences, Beijing 100049, China
}

\section{A R T I C L E I N F O}

\section{Article history:}

Received 8 June 2018

Accepted 23 July 2018

Published 5 November 2018

\section{Keywords:}

Methanol to olefin (MTO)

Product selectivity

Metal modification

Diffusion hindrance

Core-shell like

\begin{abstract}
A B S T R A C T
The SAPO-34 catalysts were modified with metal cations by different processes (conventional ion exchange (CIE), template-assisted ion incorporation (TII) and alcoholic ion exchange (AIE)), systematically characterized by XRD, XRF, $\mathrm{N}_{2}$ adsorption-desorption, UV-VIS, $\mathrm{H}_{2}$-TPR, EPR, SEM, EDX, $\mathrm{XPS}, \mathrm{NH}_{3}$-TPD, ${ }^{1} \mathrm{H}$ NMR and IGA, and applied in MTO reaction. The metal cations incorporation introduces extra diffusion hindrance by metallic species located in the cavity of SAPO-34. In particular, the Zn cations-modified SAPO-34 catalysts exhibit core-shell like structure, with Si-rich and Zn-rich sublayer near the external surface, which favors the coke deposition at the beginning of MTO reaction, exerts marked impact on the diffusion of the generated products with relatively large molecular size (e.g. propylene), and significantly increases the selectivity to ethylene and the ratio of ethylene to propene in the MTO reaction.
\end{abstract}

(C) 2018, Dalian Institute of Chemical Physics, Chinese Academy of Sciences. Published by Elsevier B.V. All rights reserved.

\section{Introduction}

Light olefins (ethylene and propylene) are the backbone feed-stocks of the petrochemical industry. During the past decades, the methanol-to-olefin (MTO) process has been developed as the most successful non-petrochemical route for the generation of light olefins due to the ever-increasing cost of crude oil and the demand of light olefins [1-3]. In particular, SAPO-34 with the CHA structure demonstrates excellent catalytic performance in the MTO reaction due to the contribution of small pore, medium acidity, and high thermal/hydrothermal stability. It is widely accepted that the MTO reaction follows the hydrocarbon pool (HCP) mechanism, with the cyclic organic species and the corresponding carbenium ions as the active

\footnotetext{
* Corresponding author. Tel: +86-411-84379998; Fax: +86-411-84379289; E-mail: liuzm@dicp.ac.cn

\# Corresponding author. Tel: +86-411-84986133; Fax: +86-411-84986134; E-mail: csong@psu.edu

\$Corresponding author. Tel: +86-411-84379118; Fax: +86-411-84379289; E-mail: weiyx@dicp.ac.cn

This work was supported by the National Natural Science Foundation of China $(21603223,91745109,91545104,21473182)$, the Youth Innovation Promotion Association of the Chinese Academy of Sciences (2014165), and the Key Research Program of Frontier Sciences, CAS (QYZDY-SSW-JSC024).

DOI: 10.1016/S1872-2067(18)63141-9 | http://www.sciencedirect.com/science/journal/18722067 | Chin. J. Catal., Vol. 39, No. 11, November 2018
} 
HCP species [4-9]. The hydrogen transfer reactions between the HCP intermediates and alkenes or methanol result in coke species formation in the reaction network of MTO reaction [1]. Due to increasing diffusion barriers introduced by coke formation, the SAPO-34 catalysts display marked product shape selectivity, with an increase in ethylene selectivity and ethylene-to-propylene ratios with time on stream $[10,11]$. The catalysts deposited with a certain amount of coke favor the selectivity to ethylene and light olefins, and an optimal operation window exists with a certain coke content. Therefore, pre-coking strategy is often adopted in the industrial MTO reaction so as to increase the selectivity to ethylene and light olefins [2,10].

Metal modification, as an efficient approach to optimize the catalytic performance of SAPO-34 catalysts, has been deeply investigated. In general, metal modification is classified into isomorphous substitution (MeASPO-34) or post-treatment such as ion-exchange and impregnation. Hitherto, considerable effort has been devoted to the catalytic activity of MeASPO-34 ( $\mathrm{Me}=\mathrm{Mg}, \mathrm{Mn}, \mathrm{Fe}, \mathrm{Co}, \mathrm{Ni}, \mathrm{Zr}, \mathrm{Ce}, \mathrm{La}$, etc.) [12-16]. By contrast, there are relatively few studies focusing on the catalytic performance of ion-exchanged SAPO-34 in MTO reaction, and unsatisfying results are often obtained [17-19].

Recently, we have demonstrated that zinc cation-modified SAPO-34 catalysts prepared from conventional ion exchange (CIE) process exhibit promoting effect similar to the pre-coking approach, with enhanced selectivity to ethylene and light olefins. The zinc cations accommodation in the cavities of the shell layer and the facilitated aromatic formation over the zinc cation-modified SAPO-34 form a core-shell like structure, which introduces extra diffusion limitation for bulky hydrocarbons and increases the selectivity to ethylene and the ratio of ethylene to propylene in the MTO reaction [20]. Furthermore, a straightforward template-assisted ion incorporation (TII) process was developed, without the necessary template pre-removal and the preparation of $\mathrm{NH}_{4}$-SAPO-34 intermediate. The zinc-modified SAPO-34 catalysts prepared by the TII process also exhibit desired effect on enhancing the selectivity to ethylene and light olefins [21].

In the present study, SAPO-34 was modified with metal cations by various approaches (conventional ion exchange (CIE), template-assisted ion incorporation (TII) and alcoholic ion exchange (AIE)), the chemical state and distribution of the metal species over the metal-modified SAPO-34 catalysts were comprehensively characterized, and the impacts of metal species on the product selectivity in MTO reaction were thoroughly investigated.

\section{Experimental}

\subsection{Catalyst preparation}

The SAPO-34 powders were supplied by the Nankai University Catalyst Co., Ltd, and denoted as SP-34. The SAPO-34 powders were calcined at $600{ }^{\circ} \mathrm{C}$ for $2 \mathrm{~h}$ to remove the template and denoted as H-SP34. The metal cations-modified SAPO-34 catalysts were prepared by conventional ion exchange (CIE), tem- plate-assisted ion incorporation (TII) and alcoholic ion exchange (AIE) process, respectively.

H-SP34 was exchanged with $1 \mathrm{~mol} \mathrm{~L}^{-1} \mathrm{NH}_{4} \mathrm{NO}_{3}$ solution twice with liquid-to-solid (L/S) ratio of $10 \mathrm{~mL} \mathrm{~g}^{-1}$ at $80{ }^{\circ} \mathrm{C}$ for 2 $\mathrm{h}$, which was followed by a filtration, washing and drying procedure, and the sample was denoted as $\mathrm{NH}_{4}-\mathrm{SP} 34$.

For the CIE process, the $\mathrm{NH}_{4}$-SP34 was exchanged with 0.01 mol $\mathrm{L}^{-1} \quad \mathrm{Zn}\left(\mathrm{NO}_{3}\right)_{2} \cdot 6 \mathrm{H}_{2} \mathrm{O} / \mathrm{Cu}(\mathrm{OAC})_{2} \cdot \mathrm{H}_{2} \mathrm{O} / \mathrm{Co}\left(\mathrm{NO}_{3}\right)_{2} \cdot 6 \mathrm{H}_{2} \mathrm{O} /$ $\mathrm{Ni}\left(\mathrm{NO}_{3}\right)_{2} \cdot 6 \mathrm{H}_{2} \mathrm{O}$ solution with $\mathrm{L} / \mathrm{S}$ ratio of $30 \mathrm{~mL} \mathrm{~g}^{-1}$ at $50{ }^{\circ} \mathrm{C}$ for $4 \mathrm{~h}$, which was followed by filtration, washing and drying. The powder was calcined at $600{ }^{\circ} \mathrm{C}$ for $4 \mathrm{~h}$.

For the TII process, the uncalcined SP34 was stirred in 0.01 mol L-1 $\mathrm{Zn}\left(\mathrm{NO}_{3}\right)_{2} \cdot 6 \mathrm{H}_{2} \mathrm{O} / \mathrm{Cu}(\mathrm{OAC})_{2} \cdot \mathrm{H}_{2} \mathrm{O}$ solution with $\mathrm{L} / \mathrm{S}$ ratio of $30 \mathrm{~mL} \mathrm{~g}^{-1}$ at $50{ }^{\circ} \mathrm{C}$ for $4 \mathrm{~h}$, which was followed by a filtration, washing and drying procedure. The powder was calcined at $600{ }^{\circ} \mathrm{C}$ for $4 \mathrm{~h}[22]$.

For the AIE process, the $\mathrm{H}-\mathrm{SP} 34$ was exchanged with 0.01 mol L ${ }^{-1} \mathrm{Zn}\left(\mathrm{NO}_{3}\right)_{2} \cdot 6 \mathrm{H}_{2} \mathrm{O} / \mathrm{Cu}(\mathrm{OAC})_{2} \cdot \mathrm{H}_{2} \mathrm{O}$ solution in ethanol with $\mathrm{L} / \mathrm{S}$ ratio of $30 \mathrm{~mL} \mathrm{~g}^{-1}$ at $50{ }^{\circ} \mathrm{C}$ for $4 \mathrm{~h}$, which was followed by filtration, washing with ethanol and drying. The powder was calcined at $600{ }^{\circ} \mathrm{C}$ for $4 \mathrm{~h}$ [23].

For comparison, the zinc-modified SAPO-34 catalysts were also prepared by impregnation (IMP). The $\mathrm{NH}_{4}$-SP34 was impregnated with $\mathrm{Zn}\left(\mathrm{NO}_{3}\right)_{2} \cdot 6 \mathrm{H}_{2} \mathrm{O}$ solution at room temperature with the theoretical amount of $0.4 \mathrm{wt} \%$. The powder was dried

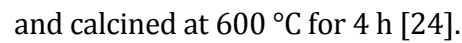

\subsection{Catalyst characterization}

X-ray diffraction (XRD) was conducted on a PANalytical X'Pert PRO X-ray diffractometer operated at $40 \mathrm{~mA}$ and $40 \mathrm{kV}$. $\mathrm{Cu} K_{\alpha}$ radiation $(\lambda=1.54059 \AA)$ was used as the X-ray source. XRD patterns were recorded in the range of $2 \theta=5^{\circ}-40^{\circ}$.

X-ray fluorescence (XRF) was conducted with a Philips Magix-601 spectrometer.

Nitrogen adsorption-desorption was conducted with a Micromeritics ASAP 2020 system at $-196^{\circ} \mathrm{C}$ after the sample was degassed at $350{ }^{\circ} \mathrm{C}$ under vacuum. The total surface area was calculated according to the BET equation. The micropore volume, external surface area and micropore surface area were calculated by the $t$-plot method. The total pore volume was determined from the amount adsorbed at the relative pressure of 0.99 .

Ultraviolet-visible (UV-vis) spectra were recorded at room temperature using a VARIAN Cary-5000 UV-Vis-NIR spectrophotometer equipped with an integration sphere in the 200-800 nm wavelength range.

Temperature-programmed reduction by $\mathrm{H}_{2}$ ( $\mathrm{H}_{2}$-TPR) measurements were performed with a Micromeritics $\mathrm{Au}-$ tochem II 2920. The samples were pretreated at $550{ }^{\circ} \mathrm{C}$ for 60 min in Ar. The TPR procedure was conducted from 50 to $900{ }^{\circ} \mathrm{C}$ under $10 \% \mathrm{H}_{2} / \mathrm{Ar}$. The consumption of $\mathrm{H}_{2}$ was detected by TCD.

Electron paramagnetic resonance (EPR) was performed on a Bruker A 200. The samples were dehydrated in He for $60 \mathrm{~min}$ at $500{ }^{\circ} \mathrm{C}$. The EPR spectra were recorded at $-186^{\circ} \mathrm{C}$. The location and the intensity of $\mathrm{g}$ factor were measured by Bruker's 
WINEPR program according to $h v=g \beta H$, where $h$ is Planck constant, $H$ is the actual magnetic field, and $\beta$ is the Bohr magneton.

Scanning electron microscopic (SEM) images were taken with a Hitachi TM3000 operated at an acceleration voltage of $15 \mathrm{kV}$. The sample was attached onto conductive double side carbon tapes. The crystal size distribution was calculated with software Nano Measurer.

Energy-dispersive X-ray spectroscopic (EDS) analysis was conducted with a cold field emission SEM Hitachi SU8020 equipped with a Horiba X-max silicon drift X-ray detector operated at an acceleration voltage of $20 \mathrm{kV}$.

$\mathrm{X}$-ray photoelectron spectra (XPS) were determined with a Thermo ESCALAB 250Xi. The X-ray excitation was provided by a monochromatic $\mathrm{Al} K_{\alpha}$ source $(1486.6 \mathrm{eV}, 15 \mathrm{kV}, 10.8 \mathrm{~mA})$. Binding energy (BE) values were referenced to the $\mathrm{C} 1 \mathrm{~s}$ line of residual carbon at $284.8 \mathrm{eV}$. The atomic ratio was calculated using the peak areas of $\mathrm{Si} 2 p, \mathrm{Al} 2 p, \mathrm{P} 2 p$, $\mathrm{Zn} 2 p$ and $\mathrm{Cu} 2 p$, respectively. Prior to the XPS measurements, the powders were pressed into disks with a diameter of $5 \mathrm{~mm}$.

Temperature-programmed desorption of ammonia ( $\mathrm{NH}_{3}$-TPD) was conducted with a Micromeritics Autochem II 2920. The samples were activated at $550{ }^{\circ} \mathrm{C}$ for $60 \mathrm{~min}$ in $\mathrm{He}$, then cooled down to $100{ }^{\circ} \mathrm{C}$ and subjected to $10 \% \mathrm{NH}_{3} / \mathrm{He}$ for 30 min to be saturated with $\mathrm{NH}_{3}$. The sample was then purged with He for $30 \mathrm{~min}$ to remove the physically adsorbed $\mathrm{NH}_{3}$. The measurement of the desorbed $\mathrm{NH}_{3}$ was performed from 100 to $650^{\circ} \mathrm{C}$ at a rate of $10^{\circ} \mathrm{C} / \mathrm{min}$ under He.

${ }^{1} \mathrm{H}$ MAS NMR spectra were measured on a Bruker Avance III 600 spectrometer equipped with a $14.1 \mathrm{~T}$ wide-bore magnet and a $4 \mathrm{~mm} \mathrm{H-X}$ magic angle spinning (MAS) probe. The samples were dehydrated at $400{ }^{\circ} \mathrm{C}$ for $20 \mathrm{~h}$ at a pressure of less than $10^{-3} \mathrm{~Pa}$. The resonance frequencies were $600.13 \mathrm{MHz}$. Chemical shifts were referenced to admantane at $1.74 \mathrm{ppm}$.

\subsection{MTO reaction}

Typically, the catalyst (100 mg, 40-60 mesh) was loaded in the tubular quartz fixed-bed reactor and activated under a He flow at $500{ }^{\circ} \mathrm{C}$ for $45 \mathrm{~min}$. Methanol was fed by switching the carrier gas $(8 \mathrm{~mL} / \mathrm{min})$ to pass through the saturator containing methanol at $33^{\circ} \mathrm{C}$, corresponding to the molar ratio of carrier gas to methanol of 3 and the weight hourly space velocity (WHSV) of $2.0 \mathrm{~h}^{-1}$. The exit gas was quantitatively analyzed by an online gas chromatograph (Agilent GC 6890N) using a flame ionization detector (FID) with capillary column CP-PoraPlot Q-HT $(27.5 \mathrm{~m} \times 0.53 \mathrm{~mm} \times 20 \mu \mathrm{m})$ and a thermal conductivity detector (TCD) with packed column TDX-01 (2 m $\times 3 \mathrm{~mm})$. Hydrocarbons were determined by FID, while $\mathrm{CO}, \mathrm{CH}_{4}$ and $\mathrm{CO}_{2}$ were analysed by TCD. $\mathrm{CH}_{4}$ was taken as a reference bridge between FID and TCD. The temperature of the effluent line was maintained at $150{ }^{\circ} \mathrm{C}$ by heating belt to ensure the products were in gas phase. Conversion and selectivity were computed on a carbon mole basis, reported selectivity was normalized by the total selectivity of the products observed, and dimethyl ether in the effluent is considered as a reactant.

\subsection{Diffusion properties}

The adsorption isotherms of ethane and propane were determined on a high precision intelligent gravimetric analyser (IGA100, Hiden Isochema Ltd., Warrington, UK). A sensitive microbalance (resolution of $0.1 \mu \mathrm{g}$ ) was mounted in a thermostatted enclosure to remove thermal coefficients of the weighing system and provide a high stability and accuracy. Typically, about $100 \mathrm{mg}$ samples were loaded into the microbalance bucket and outgassed under a vacuum less than $10^{-3} \mathrm{~Pa}$ at 400 ${ }^{\circ} \mathrm{C}$ for more than $10 \mathrm{~h}$ prior to the sorption measurements. The sample temperature was regulated within $0.1^{\circ} \mathrm{C}$ by a furnace. The adsorption isotherms were obtained at $20{ }^{\circ} \mathrm{C}$ and the pressure was determined by two high-accuracy Baratron pressure transducers. For each step, the amount of adsorbate (ethane $>99.99 \%$ purity, propane $>99.8 \%$ purity) introduced into the system was kept small enough to keep the adsorption process isothermal. The dosing continued until the entire equilibrium adsorption isotherm was obtained. The adsorption kinetics curve of ethane was recorded at a pressure of $10 \mathrm{mba}$.

\subsection{Analysis of retained organics}

The retained organics in the catalysts after reaction were analyzed with GC-MS. The catalysts were dissolved in $20 \% \mathrm{HF}$ solution in a screwcap Teflon vial, and the organic compounds were extracted with $\mathrm{CH}_{2} \mathrm{Cl}_{2}$ and analyzed by an Agilent $7890 \mathrm{~A}$ Gas Chromatograph equipped with an Agilent 5795C Mass Selective Detector with a HP-5 capillary column $(30 \mathrm{~m}, 0.25 \mathrm{~mm}$ i.d., stationary phase thickness $0.25 \mu \mathrm{m}$ ) and an FID detector. The structures annotated onto the chromatograms are peak identifications reference to NIST database. The amount of hydrocarbon compounds was normalized with $\mathrm{C}_{2} \mathrm{Cl}_{6}$ as the internal standard [25].

Thermo-gravimetric analysis (TGA) and differential thermogravimetric (DTG) with an SDT Q 600 were used to measure the coke removal. The sample was heated from room temperature to $900{ }^{\circ} \mathrm{C}$ at a rate of $10{ }^{\circ} \mathrm{C} \mathrm{min}-1$ under flowing air $(100$ $\mathrm{mL} \mathrm{min}^{-1}$ ). The samples after methanol reaction at $500{ }^{\circ} \mathrm{C}$ for 5 min were kept isothermal in $150{ }^{\circ} \mathrm{C}$ for additional $30 \mathrm{~min}$ for complete removal of adsorbed water.

\section{Results and discussion}

\subsection{Structural property and metal amount information: $X R D$, $X R F$ and $N_{2}$ adsorption-desorption}

The morphology and crystal size observed from SEM of H-SP34 are typical cubic crystals with average size of approximately $7 \mu \mathrm{m}$ (Figs. S1 and S2). As shown in Fig. 1, no phases related to the corresponding metal species are observed; for instance, no diffraction peaks can be detected for $\mathrm{ZnO}$ crystallites (JCPD $=31.6^{\circ}, 34.2^{\circ}, 36.1^{\circ}$ ) [26] nor for CuO phase (JCPD = $35.29^{\circ}$ and $\left.38.49^{\circ}\right)[24,27,28]$, indicating that the exchanged metal species are dispersed homogeneously. The crystallinity of samples modified with the conventional ion exchange (CIE) was maintained well, indicating the integrity of the texture 

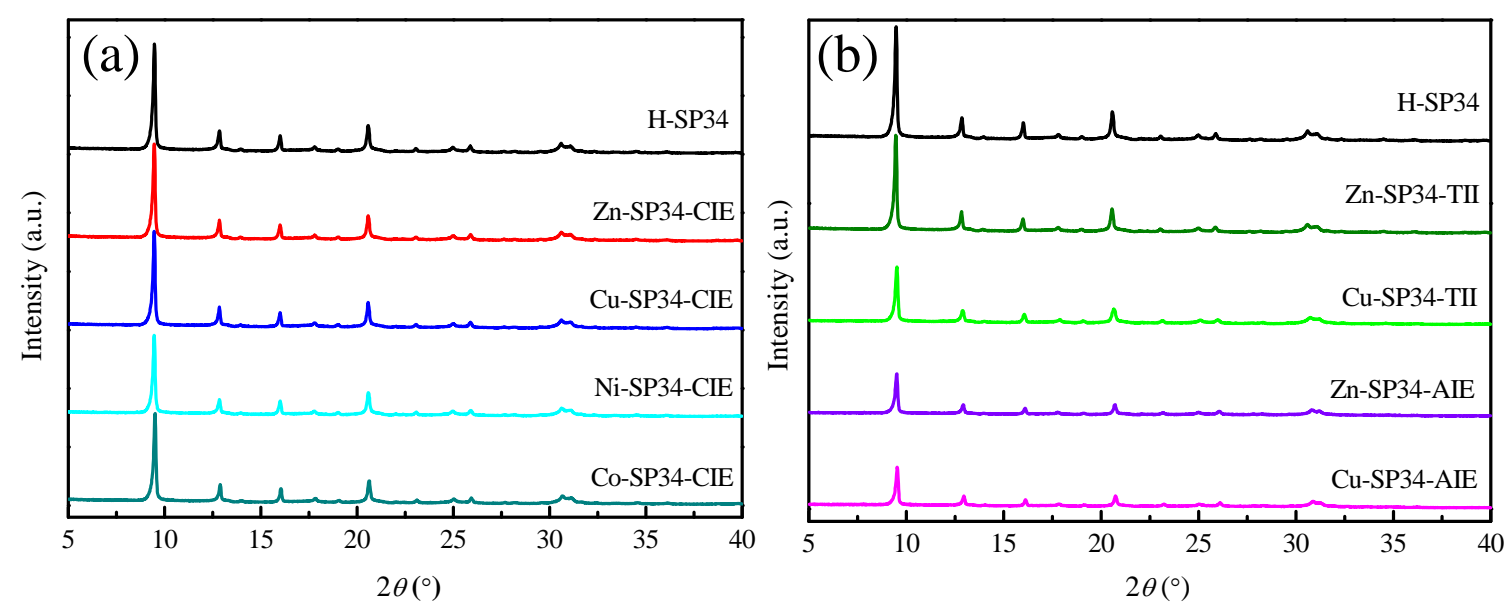

Fig. 1. XRD patterns of (a) H-SP34 and Me-SP34-CIE (Me = Zn, Cu, Co, Ni) and (b) Me-SP34-TII and Me-SP34-AIE (Me = Zn, Cu).

property after the CIE process. For the samples prepared from the template-assisted ion incorporation (TII) process, the crystallinity of Zn-SP34-TII was maintained well, while the crystallinity of Cu-SP34-TII decreases to some extent, which might be attributed to the different metal salt precursors adopted. On the contrary, the samples prepared from alcoholic ion exchange (AIE) suffered marked decrease in the crystallinity, which is attributed to the high polarity of ethanol and the lack of protection of the H-SAPO-34 framework without the aid of ammonia ions as in the $\mathrm{NH}_{4}$-SP34 intermediate.

The chemical compositions of metal-modified SAPO-34 are summarized in Table S1. The $\mathrm{Zn}$ and $\mathrm{Cu}$ cations exhibit higher exchanged amount by contrast to $\mathrm{Ni}$ and Co cations under the identical CIE condition, which might be ascribed to the difference in dissociation energy of ligands $\left(\mathrm{H}_{2} \mathrm{O}\right)$ from hydrated metal ions [22]. Furthermore, for the samples prepared from the TII process, close $\mathrm{Zn}$ and $\mathrm{Cu}$ amounts compared with those prepared from the CIE process are observed. As for the samples prepared from the AIE process, relatively lower $\mathrm{Zn}$ and $\mathrm{Cu}$ amounts are observed, which might be attributed to the decreased crystallinity and the lower solubility of metal salt in ethanol by comparison to water.

The texture properties of H-SP34 and Me-SP34-CIE (Me = $\mathrm{Zn}, \mathrm{Cu}$ ) were further investigated by $\mathrm{N}_{2}$ adsorption-desorption. As shown in Fig. S3, isotherms for the samples are similar in pattern, and classified as a type I isotherm. As shown in table $\mathrm{S} 2$, the H-SP34 and Me-SP34-CIE ( $\mathrm{Me}=\mathrm{Zn}, \mathrm{Cu}$ ) exhibit similar surface area and pore volume, indicating the well maintenance of the texture property after the CIE process, which is in good agreement with the XRD analysis.

\subsection{Chemical state information: UV-Vis, $H_{2}$-TPR and EPR}

The chemical states of metal species were characterized with UV-Vis spectroscopy (Fig. 2). H-SP34 exhibits a band located at around $254 \mathrm{~nm}$, which is assigned to a charge transfer (CT) band of the SAPO framework [27,29]. And the band might be attributed to the impurities, special entities embedded in the molecular sieve matrix, or intrinsic parts of the molecular sieve lattice $[29,30]$. For the Zn-modified samples, beside the CT band of the SAPO framework, no absorption peak attributed to the $\mathrm{ZnO}$ particle (at around $370 \mathrm{~nm}$ ) is observed [31-34], which is well in accordance with the XRD result that no peaks of $\mathrm{ZnO}$ species could be detected. The $\mathrm{Cu}$-modified samples exhibit peak at about $225 \mathrm{~nm}$ with a marked increase in intensity, which is ascribed to the ligand-to-metal charge transfer (LMCT) transitions from $\mathrm{O}_{\text {zeolite }}$ to isolated $\mathrm{Cu}^{2+} / \mathrm{Cu}^{+}$ions. Meanwhile, the broad band at around $788 \mathrm{~nm}$ is assigned to $d-d$ transitions of isolated $\mathrm{Cu}^{2+}$ ions [27]. The nearly identical band position of $\mathrm{Cu}$-modified samples indicates the similar chemical environment of the $\mathrm{Cu}$ species [27].

$\mathrm{H}_{2}$-TPR measurements were performed to investigate the reducibility of metal species (Fig. 3, S4). It has been reported that the strongly stabilized $\mathrm{Zn}^{2+}$ cations in exchangeable site cannot be reduced even at $800{ }^{\circ} \mathrm{C}$, the binuclear $(\mathrm{Zn}-\mathrm{O}-\mathrm{Zn})^{2+}$ clusters should be reduced at around $400{ }^{\circ} \mathrm{C}[35,36]$, and the reduction of bulk $\mathrm{ZnO}$ particles occurs at lower temperature relative to the strongly stabilized $\mathrm{Zn}^{2+}$ cations [31,35] Zn-SP34-IMP with similar Zn amount was prepared and presented a remarkable $\mathrm{H}_{2}$ consumption peak in temperature range of $400-600{ }^{\circ} \mathrm{C}$. By contrast, Zn-SP34-CIE and Zn-SP34-TII show very low $\mathrm{H}_{2} / \mathrm{Zn}$ ratio (Fig. 3), indicating that the zinc spe-

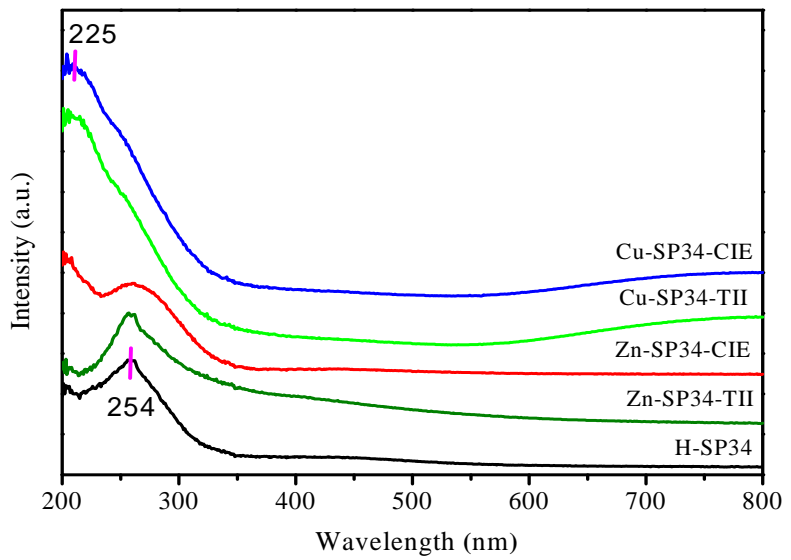

Fig. 2. UV-Vis spectra of H-SP34, Me-SP34-CIE and Me-SP34-TII (Me = $\mathrm{Zn}, \mathrm{Cu})$. 


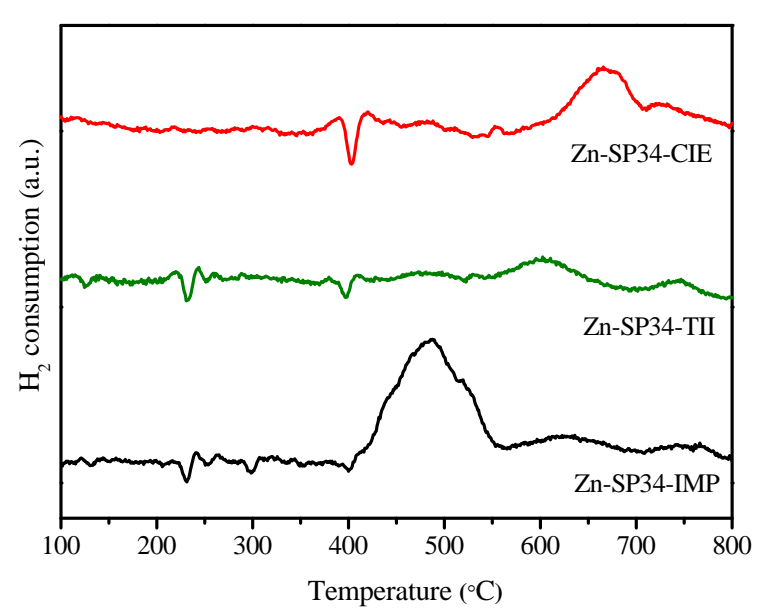

Fig. 3. $\mathrm{H}_{2}$-TPR profiles of Zn-SP34-CIE, Zn-SP34-TII and Zn-SP34-IMP.

cies mainly exist in the form of zinc cations for Zn-SP34-CIE and Zn-SP34-TII. As for Cu-modified samples (Fig. S4), the $\mathrm{H}_{2}$ consumption signal at low temperature (from 200 to $400{ }^{\circ} \mathrm{C}$ ) is assigned to the reduction of isolated $\mathrm{Cu}^{2+}$ to $\mathrm{Cu}^{+}$and $\mathrm{CuO}$ to $\mathrm{Cu}^{0}$, and the $\mathrm{H}_{2}$ consumption signal at high temperature (from 400 to $650{ }^{\circ} \mathrm{C}$ ) is ascribed to the reduction of highly stable $\mathrm{Cu}^{+}$to $\mathrm{Cu}^{0}$ at the exchangeable sites $[24,27,37]$.

In particular, the coordination environments of isolated $\mathrm{Cu}^{2+}$ ions are probed with EPR (Fig. 4). Since $\mathrm{Cu}$ species including $\mathrm{Cu}^{+}$ions and $\mathrm{CuO}$ do not produce EPR signals [38], for $\mathrm{Cu}$-modified samples, the isolated $\mathrm{Cu}^{2+}$ at $\mathrm{g} / /=2.39$ (hyperfine splitting originated from the coupling between the unpaired electron and $\mathrm{Cu}$ nuclear) and $g_{\perp}=2.06$ are discerned, corresponding to the $\mathrm{Cu}^{2+}$ cations that display axial symmetry and are coordinated to three framework oxygen atoms in site (I) shown in Fig. S5 [28,39,40].

\subsection{Distribution of metal species: XPS and EDS}

The chemical states of metal species in metal-modified SAPO-34 were measured by XPS. Similar to the possible ionic $\mathrm{Cu}$ species in $\mathrm{Cu} /$ molecular sieve (Fig. S6(a)) [41], the zinc spe-

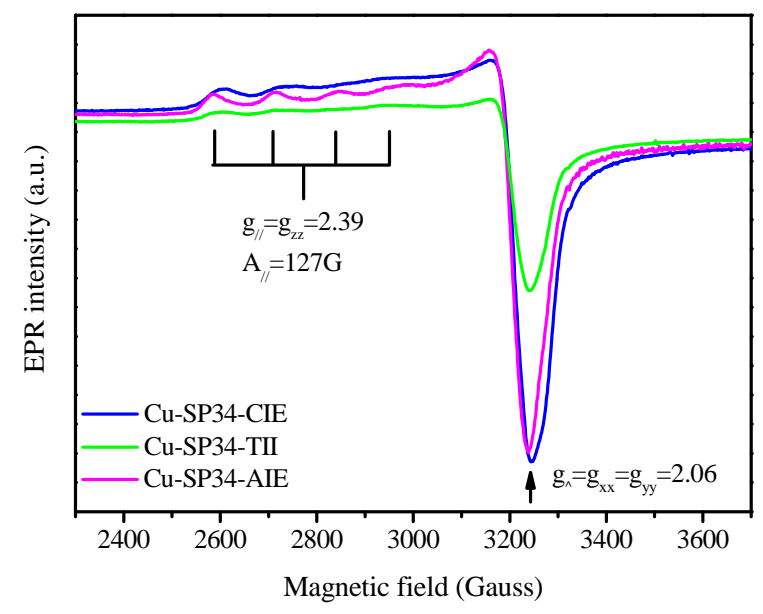

Fig. 4. EPR spectra of $\mathrm{Cu}-\mathrm{SP} 34-\mathrm{CIE}, \mathrm{Cu}-\mathrm{SP} 34-\mathrm{TII}$ and $\mathrm{Cu}-\mathrm{SP} 34-\mathrm{AIE}$. cies can exist as $\mathrm{ZnOH}^{+}$ions that located on Brönsted sites or as isolated $\mathrm{Zn}^{2+}$ cations $\left(\mathrm{O}-\mathrm{Zn}^{2+}-0\right)$ that replace two protons. In addition, the $(\mathrm{Zn}-\mathrm{O}-\mathrm{Zn})^{2+}$ species can be formed from two $\mathrm{ZnOH}^{+}$groups through the reaction as given in Fig. S6(b) $[32,34]$.

As shown in XPS spectra (Fig. S7), Zn-SP34-CIE shows the binding energy (BE) of $\mathrm{Zn} 2 p_{3 / 2}$ core level at $1023.0 \mathrm{eV}$ and the $\mathrm{Zn} 2 p_{1 / 2}$ core level at $1046.0 \mathrm{eV}$, and the area of $\mathrm{Zn} 2 p_{3 / 2}$ peak is roughly twice the area of $\mathrm{Zn} 2 p_{1 / 2}$ peak. Both of the peaks are symmetrical and narrow, indicating the single metallic state of $\mathrm{Zn}$ species [26]. It has been reported that the $\mathrm{Zn}$ species localized at the cation exchanged sites show a high BE than $\mathrm{ZnO}$ due to the higher electronegativity of the lattice oxygen of the zeolite than the $\mathrm{O}^{2-}$ ligand in bulk zinc oxide $[34,42,43]$. Therefore, the peak with BE 1023.0 and $1046.0 \mathrm{eV}$ can be reasonably assigned to $\mathrm{Zn}^{2+}$ cations in the exchangeable sites [44]. Similar chemical states are observed for Zn-SP34-TII and Zn-SP34-AIE. As for $\mathrm{Cu}$-SP34-CIE, $\mathrm{Cu} 2 p_{3 / 2}$ peak locates at $933.6 \mathrm{eV}$ while the $\mathrm{Cu} 2 p_{1 / 2}$ locates around $953.3 \mathrm{eV}$, which is attributed to the existence of isolated $\mathrm{Cu}^{2+}$ cations $[22,27,45]$. Likewise, the $\mathrm{Cu}$ cations also exist in the form of isolated $\mathrm{Cu}^{2+}$ cations for Cu-SP34-TII and Cu-SP34-AIE based on XPS analysis.

The distributions of metal species were further investigated by XPS. As shown in Table 1, for the Zn-modified samples, the $\mathrm{Zn} / \mathrm{Si}$ ratios in the subsurface is higher than the bulk, indicating that the incorporated $\mathrm{Zn}$ cations mainly locate on the sublayer near the external surface, which is strongly related to the Si-rich subsurface in the pristine SAPO-34 crystals $[46,47]$. Defining the $(\mathrm{Zn} / \mathrm{Si})_{\text {surface }} /(\mathrm{Zn} / \mathrm{Si})_{\text {bulk }}$ as surface $\mathrm{Zn}$ enrichment index $R \mathrm{zn}$ to indicate the degree of surface enrichment degree of $\mathrm{Zn}$ cations, the $R_{\mathrm{Zn}}$ index increases in the following order: Zn-SP34-CIE < Zn-SP34-TII < Zn-SP34-AIE. Therefore, the Zn-modified SAPO-34 exhibit core-shell like structure, with a thin Si-rich and Zn-rich shell.

By contrast, for the $\mathrm{Cu}$-modified samples, the $\mathrm{Cu} / \mathrm{Si}$ ratios in the outer subsurface are basically equivalent to those in the bulk, indicating that the incorporated $\mathrm{Cu}$ cations are distributed homogeneously, which is in good agreement with the study that high-temperature activation is beneficial for the homogeneous distribution and the migration of $\mathrm{Cu}$ cations inward into the crystal [45]. Additionally, the distribution of $\mathrm{Cu}$ species over Cu-SP34-CIE was investigated by EDS. As shown in Fig. S8, homogeneous $\mathrm{Cu}$ distribution over the crystal is observed, and the low EDS signal of $\mathrm{Cu}$ cations is ascribed to the low exchanged amount less than $0.4 \mathrm{wt} \%$ (Table S1).

Table 1

The metal distribution in Me-SP34-CIE, Me-SP34-TII and Me-SP34-AIE $(\mathrm{Me}=\mathrm{Zn}, \mathrm{Cu})$.

\begin{tabular}{|c|c|c|c|c|}
\hline \multirow{2}{*}{ Sample } & \multicolumn{2}{|c|}{ Composition (mol\%) } & \multicolumn{2}{|c|}{$\mathrm{Me} / \mathrm{Si}$} \\
\hline & Bulk $^{\text {a }}$ & Surface $^{b}$ & Bulk $^{a}$ & Surface ${ }^{b}$ \\
\hline Zn-SP34-CIE & $\mathrm{Si}_{0.085} \mathrm{Al}_{0.490} \mathrm{P}_{0.425}$ & $\mathrm{Si}_{0.100} \mathrm{Al}_{0.479} \mathrm{P}_{0.418}$ & 0.03 & 0.06 \\
\hline Cu-SP34-CIE & $\mathrm{Si}_{0.086} \mathrm{Al}_{0.494} \mathrm{P}_{0.420}$ & $\mathrm{Si}_{0.097} \mathrm{Al}_{0.489} \mathrm{P}_{0.414}$ & 0.04 & 0.05 \\
\hline Zn-SP34-TII & $\mathrm{Si}_{0.089} \mathrm{Al}_{0.498} \mathrm{P}_{0.413}$ & $\mathrm{Si}_{0.118} \mathrm{Al}_{0.473} \mathrm{P}_{0.408}$ & 0.03 & 0.13 \\
\hline Cu-SP34-TII & $\mathrm{Si}_{0.089} \mathrm{Al}_{0.496} \mathrm{P}_{0.415}$ & $\mathrm{Si}_{0.140} \mathrm{Al}_{0.483} \mathrm{P}_{0.377}$ & 0.04 & 0.04 \\
\hline Zn-SP34-AIE & $\mathrm{Si}_{0.088} \mathrm{Al}_{0.497} \mathrm{P}_{0.414}$ & $\mathrm{Si}_{0.169} \mathrm{Al}_{0.474} \mathrm{P}_{0.356}$ & 0.01 & 0.09 \\
\hline Cu-SP34-AIE & $\mathrm{Si}_{0.089} \mathrm{Al}_{0.500} \mathrm{P}_{0.411}$ & $\mathrm{Si}_{0.178} \mathrm{Al}_{0.480} \mathrm{P}_{0.342}$ & 0.02 & 0.02 \\
\hline
\end{tabular}
a Obtained from XRF analysis. ${ }^{\mathrm{b}}$ Obtained from XPS analysis. 


\subsection{Catalytic performance}

Catalytic tests of MTO performed at $500{ }^{\circ} \mathrm{C}$ under the conditions close to the industrial application are summarized in Fig. 5(a) and (b). Compared with H-SP34, both the Zn-modified SAPO-34 catalysts and Cu-modified SAPO-34 catalysts improve the selectivity to ethylene, and much marked improvements are obtained over Zn-modified SAPO-34 catalysts. The initial selectivity to ethylene increases from $38 \%$ for H-SP34 to approximately $42 \%, 43 \%$ and $44 \%$ for Zn-SP34-CIE, Zn-SP34-TII and Zn-SP34-AIE, respectively. Consequently, the ratios of ethylene to propylene are enhanced after the metal modification (Fig. 5(c) and (d)). Likewise, higher ratios of ethylene to propylene are obtained over the Zn-modified SAPO-34 catalysts. The initial ratio of ethylene to propylene increases from about 1 for H-SP34 to 1.1, 1.2 and 1.3 for Zn-SP34-CIE, Zn-SP34-TII and Zn-SP34-AIE, respectively. After the metal modification, with the predominant generation of ethylene, the selectivity to products with higher carbon number (e.g. $\mathrm{C}_{3} \mathrm{H}_{6}, \mathrm{C}_{3} \mathrm{H}_{8}, \mathrm{C}_{4}, \mathrm{C}_{5+}$ ) are decreased (Fig. S9-S11). However, catalyst lifetimes are slightly reduced over metal-modified SAPO-34 catalysts (Fig. S12).
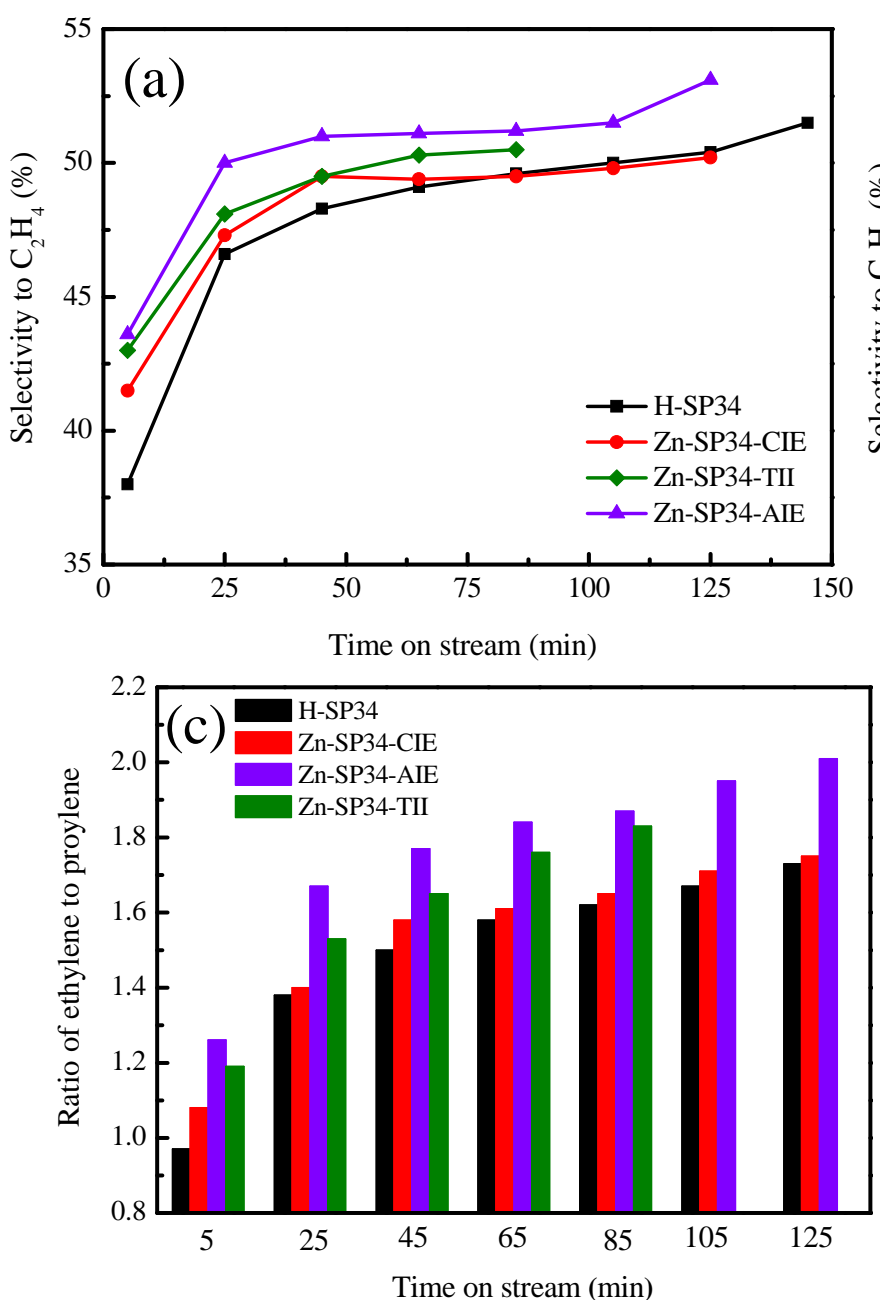

\subsection{Acid properties: $\mathrm{NH}_{3}$-TPD and ${ }^{1} \mathrm{H}$ MAS NMR}

The acidity of catalysts plays a vital role in the product selectivity in MTO reaction. Therefore, the acidity of the H-SP34 and the metal-modified samples was measured by $\mathrm{NH}_{3}$-TPD (Fig. 6). All the samples show two desorption peaks at 100-300 ${ }^{\circ} \mathrm{C}$ and $300-500{ }^{\circ} \mathrm{C}$. The low-temperature desorption peak corresponds to the ammonia adsorbed on the weak acid sites originated from the structural defect $\mathrm{OH}$ groups (e.g. Si-OH, $\mathrm{P}-\mathrm{OH}$ and $\mathrm{Al}-\mathrm{OH}$ ). The high-temperature desorption peak is ascribed to the ammonia attached to Brönsted acid sites in the form of bridging hydroxyl groups. Both the two peaks decrease in intensity after the CIE process, indicating the decreased amount of both weak and strong acid sites, which is strongly related to the exchanged metal amount obtained by the XRF analysis (Table S1). The higher exchanged metal amounts, the more distinct decrease in the acid amounts of both weak and strong acid sites. Additionally, the position of the high-temperature peak shifts to lower temperature, indicating that the slight decrease of strong acid sites.

Similarly, decreased acid amounts of both weak and strong acid sites (manly weak acid sites) are observed for the samples
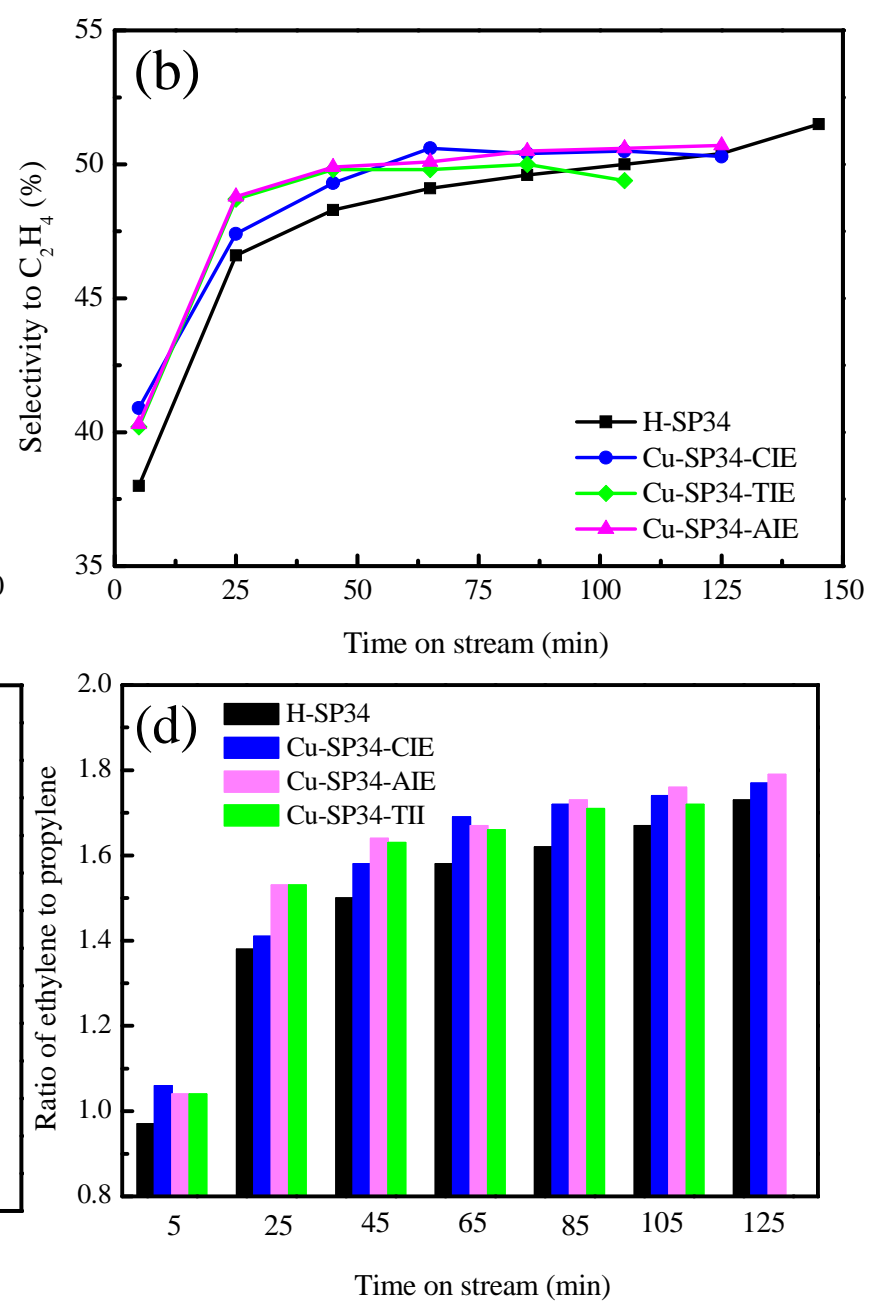

Fig. 5. The selectivity to $\mathrm{C}_{2} \mathrm{H}_{4}$ over (a) H-SP34 and Zn-modified SAPO-34 and (b) $\mathrm{H}-\mathrm{SP} 34$ and Cu-modified SAPO-34; The ratio of $\mathrm{C}_{2} \mathrm{H}_{4}$ to $\mathrm{C}_{3} \mathrm{H}_{6}$ over (c) H-SP34 and Zn-modified SAPO-34 and (d) H-SP34 and Cu-modified SAPO-34. 

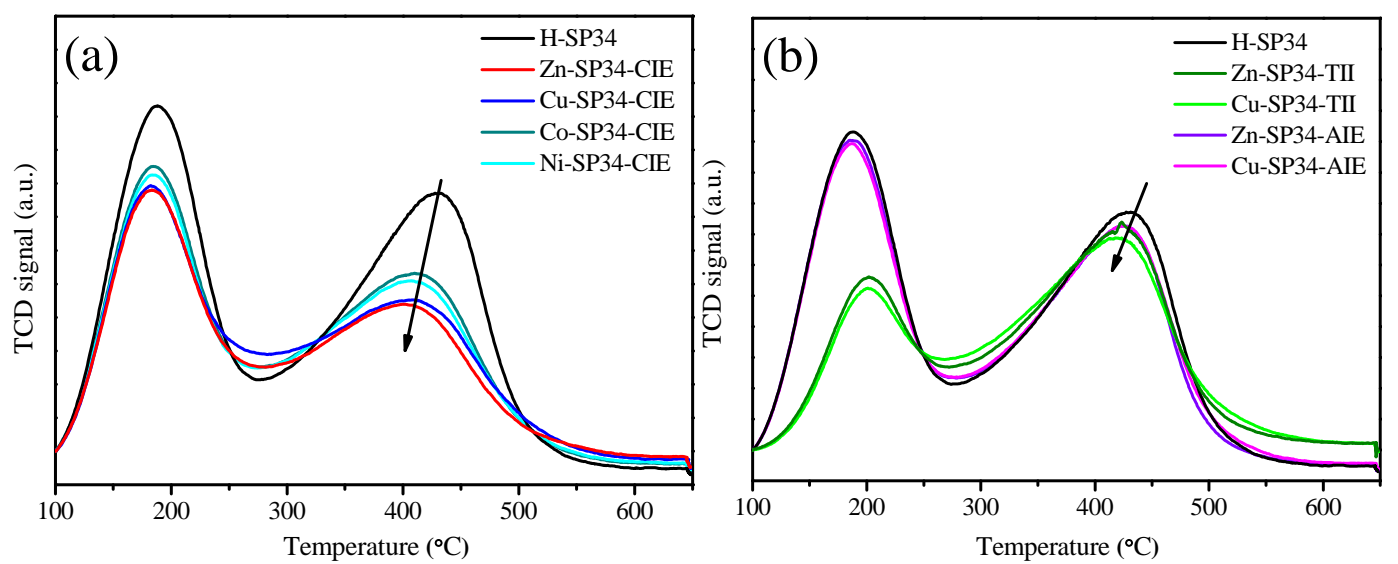

Fig. 6. $\mathrm{NH}_{3}$-TPD profiles of (a) H-SP34, Me-SP34-CIE (Me = Zn, Cu, Co, Ni), (b) Me-SP34-TII, and Me-SP34-AIE (Me = Zn, Cu).

prepared by the TII process, which is consistent with the high incorporated metal amount confirmed by the XRF analysis (Table S1). By contrast, the acid amount only decreases slightly for the samples prepared by the AIE process, which is ascribed to the low exchanged metal amount.

In particularly, it should be noted that the catalytic active sites of MTO reaction are the Brönsted acid sites of molecular sieves, and the Brönsted acid sites cannot be classified from the Lewis acid sites by $\mathrm{NH}_{3}$-TPD. Therefore, the Brönsted acid sites of H-SP34 and Me-SP34-CIE (Me = Zn, Cu) are characterized by ${ }^{1} \mathrm{H}$ MAS NMR spectroscopy (Fig. 7). Signals at $3.6 \mathrm{ppm}$ is characteristic of Brönsted acidic sites from bridging $\mathrm{OH}$ groups [Si(OH)Al]. Signals at $0-2.4 \mathrm{ppm}$ are assigned to $\mathrm{P}-\mathrm{OH}, \mathrm{Si}-\mathrm{OH}$, and Al-OH groups [48]. After the CIE process, the density of $\mathrm{Si}(\mathrm{OH}) \mathrm{Al}$ decreased from $0.86 \mathrm{mmol} \mathrm{g}^{-1}$ for H-SP34 to 0.82 and $0.67 \mathrm{mmol} \mathrm{g}^{-1}$ for $\mathrm{Zn}$-SP34-CIE and Cu-SP34-CIE, respectively.

It is generally believed that enhanced selectivity to propylene is observed over catalysts with milder acidity, owing to the facilitated olefin-based reaction route for the generation of propylene and higher olefins, as well as the inhibition of hydrogen transfer reactions that consume olefin products, especially propylene $[1,49]$. In the present work, even the lowered acid density was observed over metal cations-modified SAPO-34 catalysts, the propylene generation was depressed.

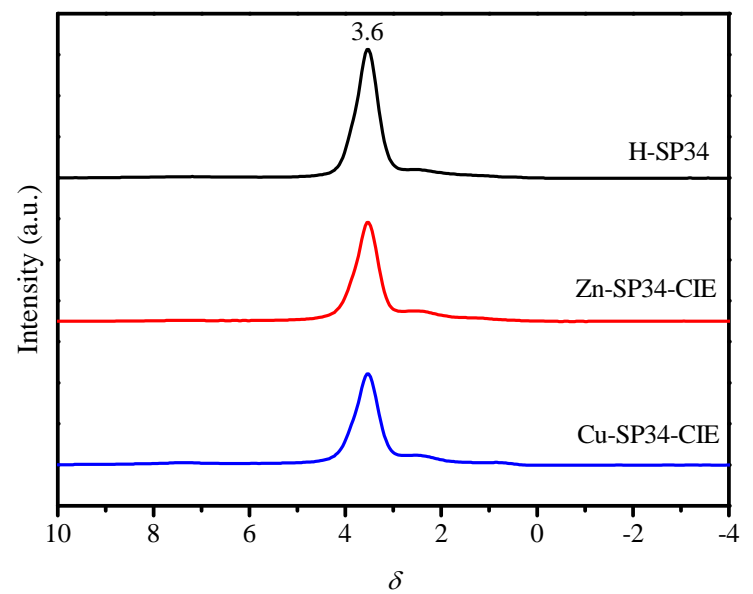

Fig. 7. ${ }^{1} \mathrm{H}$ MAS NMR spectra of H-SP34 and Me-SP34-CIE $(\mathrm{Me}=\mathrm{Zn}, \mathrm{Cu})$.
Therefore, the enhanced ethylene selectivity and ethylene to propylene ratio cannot be attributed to the acid property adjustment with metal ion incorporation.

\subsection{Diffusive properties: IGA}

The adsorption isotherms of ethane and propane on H-SP34, Zn-SP34-CIE and Cu-SP34-CIE measured by IGA (Fig. 8) are typical Langmuir type-I form according to IUPAC isotherm classification, which is saturated at low pressure and then increases slightly with further increase of pressure [50]. The adsorption capacity of ethane is higher than that of pro-
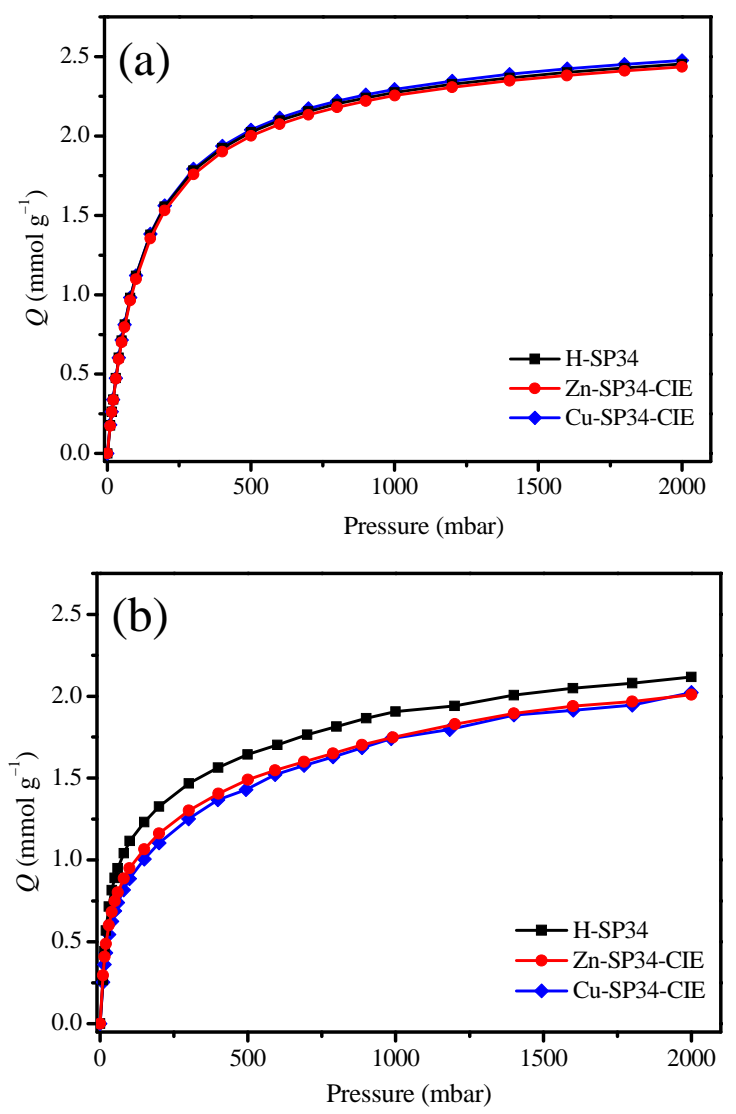

Fig. 8. The adsorption isotherms of ethane (a) and propane (b) on $\mathrm{H}-\mathrm{SP} 34$ and Me-SP34-CIE $(\mathrm{Me}=\mathrm{Zn}, \mathrm{Cu})$. 
pane for the samples, which is ascribed to the larger molecular size of propane. Compared with H-SP34, Zn-SP34-CIE and Cu-SP34-CIE show similar saturation adsorption capacities of ethane and decreased saturation adsorption capacities of propane.

The diffusion properties during the initial stage of uptake are described with the derived equation from Fick's second law [51]:

$$
\frac{q(t)}{q(m)}=\frac{6}{\sqrt{\pi}} \sqrt{\frac{D}{r^{2}}} \sqrt{t}
$$

where $q(t) / q(m)$ is the normalized loading, $D$ is the diffusivity, $r$ is the characteristic diffusion length, and $t$ is time.

The adsorption kinetics curves of ethane and propane under 10 mba are shown in Fig. S13. The characteristic diffusion time $\left(D / r^{2}\right)$ of $\mathrm{Zn}$-SP34-CIE and Cu-SP34-CIE is lower than that of H-SP34 for ethane and propane. Combined with characteristic diffusion length $r=7 \mu \mathrm{m}$, the diffusivity $D$ is obtained and shown in Table 2. The diffusivity of ethane is higher than that of propane over the samples, and diffusivity of ethane and propane over Zn-SP34-CIE and Cu-SP34-CIE is lower than that over H-SP34. The IGA results demonstrate that the incorporated metal cations in the CHA cavity introduce extra diffusion limitation for the products with both small molecular size (e.g. ethane) and relatively large dynamic diameter (e.g. propane), but much increased diffusion hindrance is encountered for bulky molecules.

In the MTO reaction, the diffusion of the generated products (e.g. ethylene and propylene) from the cavity of SAPO-34 crystals to the effluent phase is a critical step. Based on the IGA analysis, it is deduced that the incorporated metal cations introduce extra diffusion limitation for the generated products, and an increased diffusion hindrance is encountered for the relatively large-sized products such as propylene, butylene and $\mathrm{C}_{5+}$, which results in the enhanced selectivity to ethylene and increased ratio of ethylene to propylene [20].

In particular, the Zn-modified SAPO-34 exhibits core-shell like structure, with a thin Zn-rich sublayer near the external surface, which might result in more marked diffusion limitation for the generated bulky products. As shown in Fig. 5, much marked increased selectivity to ethylene and ratio of ethylene to propylene are obtained over Zn-modified SAPO-34 compared with Cu-modified SAPO-34. The higher selectivity to ethylene is strongly correlated with the enrichment of incorporated $\mathrm{Zn}$ cations in the cavity near the external surface. Furthermore, higher selectivities to ethylene are observed over Zn-SP34-TII and Zn-SP34-AIE compared with Zn-SP34-CIE, which effectively rationalizes the relationship between the enhanced selectivity to ethylene and the enrichment of Zn cat-

Table 2

The diffusivity of ethane and propane over H-SP34 and Me-SP34-CIE $(\mathrm{Me}=\mathrm{Zn}, \mathrm{Cu})$ under $10 \mathrm{mba}$.

\begin{tabular}{lcc}
\hline \multirow{2}{*}{ Sample } & \multicolumn{2}{c}{$D /\left(\mathrm{m}^{2} \mathrm{~s}^{-1}\right)$} \\
\cline { 2 - 3 } & Ethane & Propane \\
\hline H-SP34 & $2.30 \times 10^{-14}$ & $1.62 \times 10^{-15}$ \\
Zn-SP34-CIE & $1.44 \times 10^{-14}$ & $9.98 \times 10^{-16}$ \\
Cu-SP34-CIE & $6.44 \times 10^{-15}$ & $1.02 \times 10^{-15}$ \\
\hline
\end{tabular}

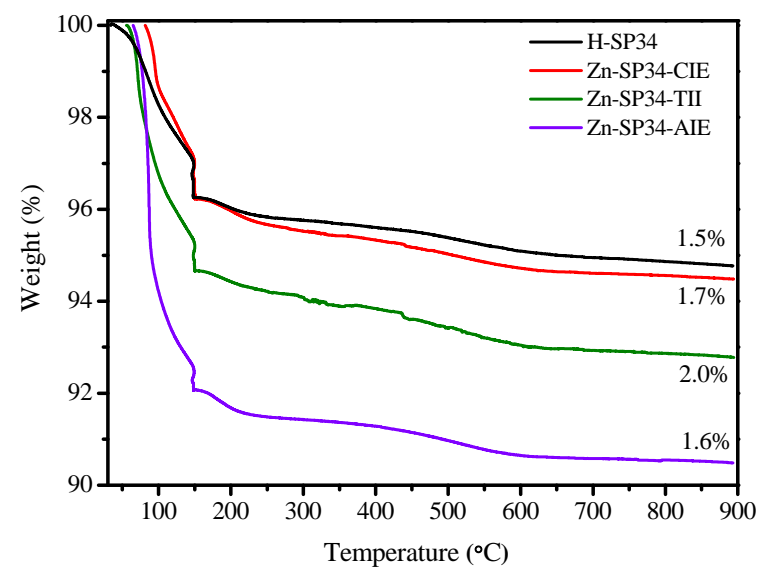

Fig. 9. TG curves of H-SP34 and Zn-modified SAPO-34 after methanol reaction for $5 \mathrm{~min}$.

ions in cavity of shell layer in the Zn-modified SAPO-34 with core-shell like structure.

\subsection{Analysis of the retained species: GC-MS and TG-DTA}

Beside metal species incorporation, coke formation over the metal-modified SAPO-34 may impart extra diffusion hindrance for generated products. The retained species over H-SP34 and Zn-modified SAPO-34 catalysts were analyzed by GC-MS and TG-DTA. As shown in Fig. S14, the deposited coke mainly composed of benzene, methyl-substituted benzene, naphthalene and methyl-substituted naphthalenes. TG-DTA was performed to determine the amount of coke deposition (Fig. 9). The weight loss below $150{ }^{\circ} \mathrm{C}$ corresponds to the removal of physically adsorbed water, while the weight loss between 150 and $900{ }^{\circ} \mathrm{C}$ corresponds to trapped organic species. The weight loss from coke removal of the catalysts after reaction for $5 \mathrm{~min}$ is $1.5 \%$, $1.7 \%, 2.0 \%$ and $1.6 \%$ for H-SP34, Zn-SP34-CIE, Zn-SP34-TII and Zn-SP34-AIE, respectively. Zn modification slightly increases the coke amount and introduces extra diffusion hindrance for the generated products, especially those with relatively large molecular size (e.g. propylene, $\mathrm{C}_{4}, \mathrm{C}_{5+}$ ), which results in the enhanced selectivity to ethylene and ratio of ethylene to propylene in the MTO reaction.

\section{Conclusions}

The incorporation of metal cations into SAPO-34 introduces extra diffusion hindrance for the generated products, especially the products with relatively large diameter (e.g. propylene), leading to enhanced selectivity to ethylene and the increased ratio of ethylene to propylene in MTO reaction. In particular, the Zn-modified SAPO-34 catalysts exhibit core-shell like structure, with the incorporated $\mathrm{Zn}$ cations mainly located in the cavity of the shell layer. Zn modification for SAPO-34 catalysts favored the quick establishment of catalytic environment for effective MTO reaction with the selective production of ethylene. The core-shell like structure and slightly increased coke deposition over Zn-modified SAPO-34 exerted extra diffusion limitation of the generated products, especially the bulky 


\section{Graphical Abstract}

Chin. J. Catal., 2018, 39: 1821-1831 doi: 10.1016/S1872-2067(18)63141-9

Enhancing ethylene selectivity in MTO reaction by incorporating metal species in the cavity of SAPO-34 catalysts

Jiawei Zhong, Jingfeng Han, Yingxu Wei *, Shutao Xu, Tantan Sun, Xinwen Guo, Chunshan Song *, Zhongmin Liu * Dalian University of Technology, China; Dalian Institute of Chemical Physics, Chinese Academy of Sciences, China; Pennsylvania State University, USA;

University of Chinese Academy of Sciences, China

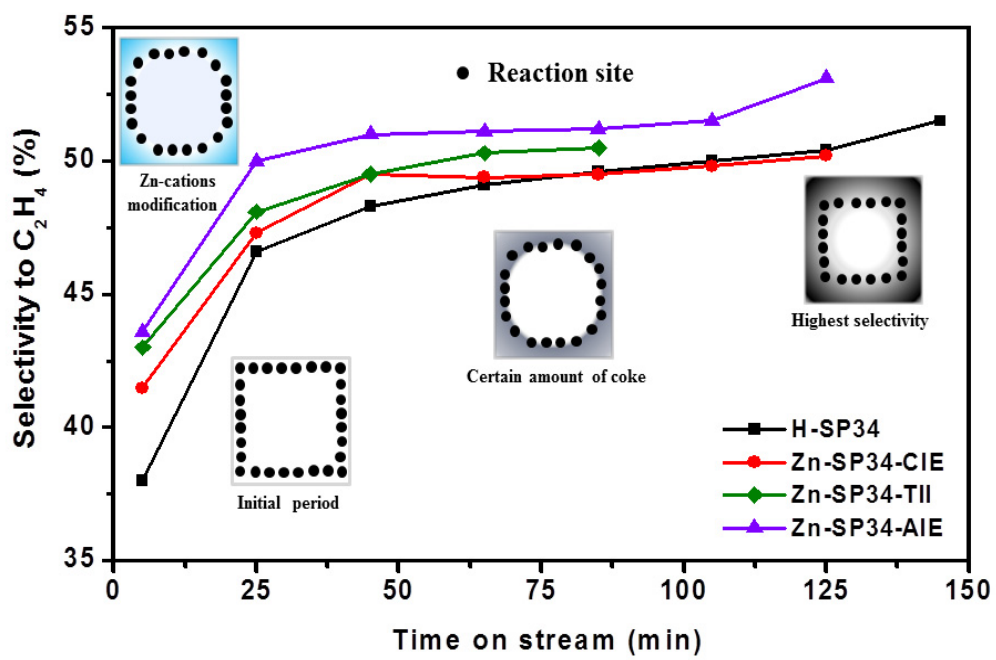

The Zn cation-modified SAPO-34 catalysts with core-shell like structure favor the quick establishment of catalytic environment for effective MTO reaction with the selective production of ethylene via introducing extra diffusion limitation for the higher hydrocarbon products.

products, leading to significantly enhanced selectivity to ethylene and the increased ratio of ethylene to propylene in MTO reaction. The relationship between the core-shell like structure, diffusion hindrance and product selectivity in MTO reaction is established, which lays the foundation for the proposed product modulation strategy for the SAPO-34 catalysts in the industrial MTO process.

\section{References}

[1] S. T. Xu, Y. C. Zhi, J. F. Han, W. N. Zhang, X. Q. Wu, T. T. Sun, Y. X. Wei, Z. M. Liu, in: C. S. Song ed., Adv. Catal., Academic Press, 2017, $61,37-122$.

[2] P. Tian, Y. X. Wei, M. Ye, Z. M. Liu, ACS Catal., 2015, 5, 1922-1938.

[3] M. Khanmohammadi, Sh. Amania, A. B. Garmarudia, A. Niaei, Chin. J. Catal., 2016, 37, 325-339.

[4] Y. Zhou, L. Qi, Y. X. Wei, C. Y. Yuan, M. Z. Zhang, Z. M. Liu, Chin. J. Catal., 2016, 37, 1496-1501.

[5] S. Ren, G. J. Liu, X. Wu, X. Q. Chen, M. H. Wu, G. F. Zeng, Z. Y. Liu, Y. H. Sun, Chin. J. Catal, 2017, 38, 123-130.

[6] X. B. Zhao, Y. Hong, L. Y. Wang, D. Fan, N. N. Yan, X. N. Liu, P. Tian, X. W. Guo, Z. M. Liu, Chin. J. Catal., 2018, 39, 1418-1426.

[7] P. F. Wu, M. Yang, W. N. Zhang, S. Zeng, M. B. Gao, S. T. Xu, P. Tian, Z. M. Liu, Chin. J. Catal., 2018, 39, 1511-1519.

[8] Y. Y. Qiao, P. F. Wu, X. Xiang, M. Yang, Q. Y. Wang, P. Tian, Z. M. Liu, Chin. J. Catal., 2017, 38, 574-582

[9] J. W. Zhong, J. F. Han, Y. X. Wei, P. Tian, X. W. Guo, C. S. Song, Z. M.
Liu, Catal. Sci. Technol., 2017, 7, 4905-4923

[10] N. Nesterenko, J. Aguilhon, P. Bodart, D. Minoux, J. P. Dath, in: L. M. Kustov ed., Zeolites and Zeolite-Like Materials, Elsevier, 2016, 189-263.

[11] B. P. C. Hereijgers, F. Bleken, M. H. Nilsen, S. Svelle, K. P. Lillerud, M. Bjorgen, B. M. Weckhuysen, U. Olsbye, J. Catal., 2009, 264, 77-87.

[12] A. Z. Varzaneh, J. Towfighi, S. Sahebdelfar, Microporous Mesoporous Mater., 2016, 236, 1-12.

[13] A. Amoozegar, M. Haghighi, S. Aghamohammadi, RSC Adv., 2016, 6, 51024-51036.

[14] E. Aghaei, M. Haghighi, Z. Pazhohniya, S. Aghamohammadi, Microporous Mesoporous Mater., 2016, 226, 331-343

[15] M. Salmasi, S. Fatemi, A. T. Najafabadi, J. Ind. Eng. Chem., 2011, 17, 755-761.

[16] L. Xu, Z. M. Liu, A. P. Du, Y. X. Wei, Z. G. Sun, Stud. Surf. Sci. Catal., 2004, 147, 445-450.

[17] M. A. Djieugoue, A. M. Prakash, L. Kevan, J. Phys. Chem. B, 2000, $104,6452-6461$.

[18] Z. D. Zhu, M. Hartmann, L. Kevan, Chem. Mater., 2000, 12, 2781-2787.

[19] S. J. Kim, J. W. Park, K. Y. Lee, G. Seo, M. K. Song, S. Y. Jeong, J. Nanosci. Nanotechnol., 2010, 10, 147-157.

[20] J. W. Zhong, J. F. Han, Y. X. Wei, S. T. Xu, Y. L. He, Y. J. Zheng, M. Ye, X. W. Guo, C. S. Song, Z. M. Liu, Chem. Commun., 2018, 54, 3146-3149.

[21] J. W. Zhong, Y. X. Wei, S. T. Xu, T. T. Sun, X. W. Guo, C. S. Song, Z. M. Liu, J. Energy Chem., 2018, DOI 10.1016/j.jechem.2018.07.017.

[22] X. Xiang, M. Yang, B. B. Gao, Y. Y. Qiao, P. Tian, S. T. Xu, Z. M. Liu, 
RSC Adv., 2016, 6, 12544-12552.

[23] M. Hong, S. G. Li, H. F. Funke, J. L. Falconer, R. D. Noble, Microporous Mesoporous Mater., 2007, 106, 140-146.

[24] J. Wang, Y. Huang, T. Yu, S. C. Zhu, M. Q. Shen, W. Li, J. Q. Wang, Catal. Sci. Technol, 2014, 4, 3004-3012.

[25] M. Guisnet, L. Costa, F. R. Ribeiro, J. Mol. Catal. A, 2009, 305, 69-83.

[26] N. H. N. Kamarudin, A. A. Jalil, S. Triwahyono, R. R. Mukti, M. A. A. Aziz, H. D. Setiabudi, M. N. M. Muhid, H. Hamdan, Appl. Catal. A, 2012, 431-432, 104-112.

[27] L. Wang, J. R. Gaudet, W. Li, D. Weng, J. Catal., 2013, 306, 68-77.

[28] S. K. Fan, J. J. Xue, T. Yu, D. Q. Fan, T. Hao, M. Q. Shen, W. Li, Catal. Sci. Technol., 2013, 3, 2357-2364.

[29] T. T. H. Dang, H. L. Zubowa, U. Bentrup, M. Richter, A. Martin, Microporous Mesoporous Mater., 2009, 123, 209-220.

[30] E. D. Garbowski, C. Mirodatos, J. Phys. Chem., 1982, 86, 97-102.

[31] C. Song, X. J. Li, X. X. Zhu, S. L. Liu, F. C. Chen, F. Liu, L. Y. Xu, Appl. Catal. A, 2016, 519, 48-55.

[32] X. J. Niu, J. Gao, Q. Miao, M. Dong, G. F. Wang, W. B. Fan, Z. F. Qin, J. G. Wang, Microporous Mesoporous Mater., 2014, 197, 252-261.

[33] Y. B. Xin, P. Y. Qi, X. P. Duan, H. Q. Lin, Y. Z. Yuan, Catal. Lett, 2013, 143, 798-806.

[34] Y. M. Jia, J. W. Wang, K. Zhang, S. B. Liu, G. L. Chen, Y. F. Yang, C. M. Ding, P. Liu, Catal. Sci. Technol., 2017, 7, 1776-1791.

[35] J. A. Biscardi, G. D. Meitzner, E. Iglesia, J. Catal., 1998, 179, 192-202.

[36] E. M. El-Malki, R. A. Van Santen, W. M. H. Sachtler, J. Phys. Chem. B, 1999, 103, 4611-4622.

[37] W. K. Su, Z. G. Li, Y. Peng, J. H. Li, Phys. Chem. Chem. Phys., 2015, 17, 29142-29149.

[38] L. Ma, Y. S. Cheng, G. Cavataio, R. W. McCabe, L. X. Fu, J. H. Li, Chem.
Eng. J., 2013, 225, 323-330.

[39] J. J. Xue, X. Q. Wang, G. S. Qi, J. Wang, M. Q. Shen, W. Li, J. Catal., 2013, 297, 56-64.

[40] Y. J. Kim, J. K. Lee, K. M. Min, S. B. Hong, I. S. Nam, B. K. Cho, J. Catal., 2014, 311, 447-457.

[41] F. Gao, E. D. Walter, M. Kollar, Y. L. Wang, J. Szanyi, C. H. F. Peden, J. Catal., 2014, 319, 1-14.

[42] A. A. Gabrienko, S. S. Arzumanov, A. V. Toktarev, I. G. Danilova, I. P. Prosvirin, V. V. Kriventsov, V. I. Zaikovskii, D. Freude, A. G. Stepanov, ACS Catal., 2017, 7, 1818-1830.

[43] S. Tamiyakul, W. Ubolcharoen, D. N. Tungasmita, S. Jongpatiwut, Catal. Today, 2015, 256, 325-335.

[44] R. A. Hunsicker, K. Klier, T. S. Gaffney, J. G. Kirner, Chem. Mater., 2002, 14, 4807-4811.

[45] P. N. R. Vennestrøm, A. Katerinopoulou, R. R. Tiruvalam, A. Kustov, P. G. Moses, P. Concepcion, A. Corma, ACS Catal., 2013, 3, 2158-2161.

[46] P. Tian, B. Li, S. T. Xu, X. Su, D. H. Wang, L. Zhang, D. Fan, Y. Qi, Z. M. Liu, J. Phys. Chem. C, 2013, 117, 4048-4056.

[47] Y. Y. Qiao, M. Yang, B. B. Gao, L. Y. Wang, P. Tian, S. T. Xu, Z. M. Liu, Chem. Commun., 2016, 52, 5718-5721.

[48] W. L. Dai, M. Scheibe, L. D. Li, N. J. Guan, M. Hunger, J. Phys. Chem. C, 2012, 116, 2469-2476.

[49] D. Chen, K. Moljord, A. Holmen, Microporous Mesoporous Mater., 2012, 164, 239-250.

[50] X. J. Li, X. H. Liu, S. L. Liu, S. J. Xie, X. X. Zhu, F. C. Chen, L. Y. Xu, RSC Adv., 2013, 3, 16549-16557.

[51] J. J. Zheng, Q. H. Zeng, Y. Y. Zhang, Y. Wang, J. H. Ma, X. W. Zhang, W. F. Sun, R. F. Li, Chem. Mater., 2010, 22, 6065-6074.

\title{
通过SAPO-34分子篮笼中引入金属物种提升甲醇制烯烃反应中乙烯选择性
}

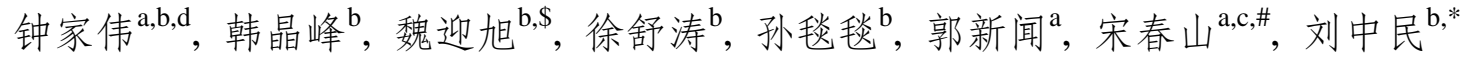 \\ ${ }^{\mathrm{a}}$ 大连理工大学化工学院, 宾州州立大学-大连理工大学联合能源研究中心, 精细化工国家重点实验室, 辽宁大连116024, 中国 \\ b 中国科学院大连化学物理研究所, 甲醇制烯烃国家工程实验室, 国家能源低碳催化与工程研发中心, \\ 洁净能源国家实验室(筹), 能源材料化学协同创新中心, 辽宁大连116023, 中国 \\ c 宾州州立大学, 宾夕法尼亚州16802, 美国 \\ $\mathrm{d}$ 中国科学院大学, 北京100049, 中国
}

摘要: 低碳烯烃(乙烯、丙烯)是化学工业极其重要的基本原料. 甲醇制烯烃(MTO)反应是重要的烯烃生产石油替代路线. 其中, 磷酸硅铝类SAPO-34分子笁在MTO反应中表现出优异的低碳烯烃选择性. 与丙烯相比, 乙烯具有更高的经济附加值, 因此提升MTO反应中乙烯的选择性有着重要的意义.

本文采用传统离子交换法(CIE)、模板辅助离子引入法(TII)和醇相离子交换法(AIE)对SAPO-34分子篮进行金属Zn、Cu 改性, 利用多种表征手段对金属Zn、Cu改性SAPO-34分子篎的物理结构、化学组成、金属物种状态与分布、酸性及扩散性 质等进行表征.

首先, 对金属Zn、Cu改性SAPO-34分子篮的物理结构和化学组成进行分析. X射线衍射表明, 相比AIE法, CIE法和TII 法改性基本保持SAPO-34分子笁的结晶度. X射线荧光分析表明, 相比Co、 Ni, 金属 Zn、Cu更易引入SAPO-34分子篮. $\mathrm{N}_{2}$ 物理吸附-脱附表明, CIE法改性能够保持SAPO-34分子笁的BET比表面积和微孔孔容. 其次, 考察了金属Zn、Cu改性 SAPO-34分子篮中金属物种的状态. 氢气-程序升温还原 $\left(\mathrm{H}_{2}-\mathrm{TPR}\right)$ 和X射线光电子能谱(XPS)结果表明, $\mathrm{Zn}$ 物种主要以孤立 态的 $\mathrm{Zn}^{2+}$ 阳离子形式存在. $\mathrm{H}_{2}-\mathrm{TPR} 、 \mathrm{XPS}$ 、紫外-可见光谱和电子顺磁共振谱结果表明, $\mathrm{Cu}$ 物种主要以孤立态的Cu ${ }^{2+}$ 阳离子 以及部分 $\mathrm{CuO}$ 形式存在. 继而对金属Zn、Cu改性SAPO-34分子笁中金属物种的分布进行表征. XPS表明, Zn阳离子改性的 SAPO-34表层富硅、富Zn, 呈类核壳结构; XPS和扫描式电镜-能量色散X射线光谱结果表明, Cu物种在Cu改性SAPO-34分子 笁中均匀分布. 进一步研究了金属Zn、Cu改性SAPO-34分子篮中酸性的变化. 氨气-程序升温脱附和核磁共振氢谱结果表 明, Zn、Cu改性SAPO-34酸性位点的酸量降低. 最后, 对金属Zn、Cu改性SAPO-34分子笁的扩散性质进行分析. 智能重量 
分析表明, Zn、Cu阳离子的引入降低探针分子(乙烷、丙烷)的扩散系数, 推断Zn、Cu阳离子的引入增加对MTO反应产物的 扩散限制. 热重表明, Zn阳离子改性SAPO-34分子䇥反应初期积炭量略微增加.

综上所述, Zn阳离子改性SAPO-34催化剂表层富硅、富Zn, 呈现类核壳结构. Zn阳离子的引入增加对MTO反应产物的 扩散限制, 而且Zn阳离子的引入促进MTO反应初始阶段的碳沉积. 因此, Zn阳离子改性SAPO-34分子筱显著增加MTO反 应产物的扩散限制, 对分子尺寸较大的反应产物的扩散限制更为明显, 从而提高MTO反应初始阶段的乙烯选择性, 增大乙 烯/丙烯比.

关键词: 甲醇制烯烃; 产物选择性; 金属改性; 扩散限制; 类核壳

收稿日期: 2018-06-08. 接受日期: 2018-07-23. 出版日期: 2018-11-05.

*通讯联系人. 电话: (0411)84379998; 传真: (0411)84379289; 电子信箱: liuzm@dicp.ac.cn

\#通讯联系人. 电话: (0411)84986133; 传真: (0411)84986134; 电子信箱: csong@psu.edu

\$通讯联系人. 电话: (0411)84379118; 传真: (0411)84379289; 电子信箱: weiyx@dicp.ac.cn

基金来源：国家自然科学基金(21603223, 91745109, 91545104, 21473182); 中国科学院青年创新促进会(2014165); 中国科学院前 沿科学重点研究计划(QYZDY-SSW-JSC024).

本文的电子版全文由Elsevier出版社在ScienceDirect上出版(http://www.sciencedirect.com/science/journal/18722067). 